\title{
FAKTOR-FAKTOR YANG BERHUBUNGAN DENGAN PRE-EKLAMSIA PADAHAMIL DI POLI KEBIDANAN RUMAH SAKIT TINGKAT II ISKANDAR MUDA BANDA ACEH TAHUN 2014
}

\author{
Fithriany $^{1}$, Fitri Susana ${ }^{2}$, Cut Yuniwati ${ }^{3}$ \\ ${ }^{1}$ Jurusan Kebidanan Politeknik Kesehatan Kemenkes Aceh \\ ${ }^{2}$ Universitas Ubudiyah Indonesia \\ ${ }^{3}$ Jurusan Kebidanan Politeknik Kesehatan Kemenkes Aceh
}

\begin{abstract}
Based the data obtained in Poly Midwifery of Grade II Hospital of IskandarMuda Banda Aceh, obtained that in 2013, of amount of pregnancy was 3.787, found 44 persons $(1,16 \%)$ of pregnant mother have hypertension, as many 106 (2,79\%) of pregnant mothers have severe pre-eklampsia and 2 (0,05\%) of pregnant mothers have eklampsia. Whereas period of 2014, of 3.188 of pregnant mothers who came to visit to Poly Midwifery of Grade II Hospital of IskandarMuda Banda Aceh, was 49 (1,53\%) have hypertension, as many 126 persons (3,95\%) have severe pre-eklampsia and as many 4 persons (0,15\%) have eklampsia.Purpose of Study: To find out factors related to pre-eklampsia in pregnant mother in PolyMidwifery of Grade II Hospital of IskandarMuda Banda Aceh, period of January up to December 2014. Method of Study: This study is in analytical survey by cross sectional approach, it was conducted in May $27^{\text {th }}$ up to June $1^{\text {st }}, 2015$, population in this study was whole pregnant mothers who came to visited to PolyMidwifery of Grade II Hospital of IskandarMuda Banda Aceh, January up to December 2014 periods, amounted to 3.188 persons, where sampling technique was using random sampling that taken randomly was 97 persons, the data is processed and analysed using chi-square $\left(x^{2}\right)$ test.Results of Study: There was correlation age to pre-eklampsia in pregnant mother with $p=0,017(p<0,05)$, there was correlation parity to pre-eklampsia in pregnant mother with $p=0,021(p<0,05)$, there was correlation history of hypertension to pre-eklampsia in pregnant mother with $p=0,035(p<0,05)$ Conlusion and Suggestion: There was correlation between age, parity and history of hypertension to pre-eklampsia in pregnant mother, expected to midwife for can give midwifery care to pregnant mother by pre-eklampsia so that may decrease the illness and death rates effect of pre-eklampsia.
\end{abstract}

Keywords : Age, Parity, History of Hypertension, Pre-eklampsia

\section{PENDAHULUAN}

Angka Kematian ibu (AKI) dan Angka Kematian Bayi (AKB) merupakan indikator penting untuk menilai tingkat kesejahteraan suatu negara dan status kesehatan masyarakat, dan bila AKI ini masih tinggi disuatu negara berarti sistem pelayanan obstetri di negara terdebut masih buruk, dan memerlukan perbaikan (Ambarwati dan Rismintari, 2009). Masalah kematian dan kesakitan ibu di Indonesia masih merupakan masalah besar dibidang kesehatan. Berdasarkan hasil Survei Demografi dan Kesehatan Indonesia (SDKI) pada tahun 2012, diperoleh hasil yang sangat mengejutkan, dimana AKI melonjak sangat signifikan dari 228/100.000 kelahiran hidup (KH) pada tahun 2007 menjadi 359 per 100.000 kelahiran hidup, kondisi ini menunjukkan bahwa sistem pelayanan obstetri kembali pada kondisi tahun 1997. Ini berarti kesehatan ibu justru mengalami kemunduran selama 15 tahun. Sedangkan untuk provinsi Aceh AKI ibu mencapai
158/100.000 kelahiran hidup (Dinas Kesehatan Provinsi Aceh, 2013.

Kematian ibu terjadi karena berbagai penyebab. Penyebab langsung kematian ibu terjadi akibat perdarahan mencapai $28 \%$, eklamsia $24 \%$, infeksi $11 \%$, dan lain-lain (33\%), sedangkan penyebab tidak langsung kematian ibu terjadi karena Kekurangan Energi Kronis (KEK) pada kehamilan (37\%), dan anemia pada kehamilan (40\%) (Depkes RI, 2010).

Pre-eklamsia dan eklamsia merupakan salah satu penyebab morbiditas dan mortilitas ibu dan janin. Di dunia angka kejadian pre-eklamsia berkisar antara 5-15\% dari seluruh kehamilan (Rahajuningsih, 2005). Pipkin dalam Betty (2012) juga mengemukakan menurut perkiraan 50.000 wanita pertahun meninggal dunia karena preeklampsia. Sedangkan di negara maju angka kejadian preeklampsia berkisar 6-7\% dan eklampsia 0,1-0,7\%. Di Indonesia, angka kematian ibu akibat pre-eklampsia di Indonesia juga cukup tinggi yaitu berkisar antara 9,8\% sampai 25\% (Amelda, 2009). 
Pre-eklamsi dalam kehamilan dapat menimbulkan dampak negatif bagi ibu dan janin, diantaranya solusio plasenta, hipofibrinogenmia, hemolisis, perdarahan otak, kelainan mata, edema, paru-paru, nekrosis hati, sindroma HELLP (Hemolisis, Elevated Liver Enzymes, dan Low Platelet). Komplikasi yang terberat ialah kematian ibu dan kematian janin intra-uterin (Wiknjosastro, 2007).

Penyebab pasti dari pre-eklampsia sampai kini masih belum diketahui, sehingga pre-eklampsia disebut sebagai "the disease of theories" dalam (Betty, 2012). Namun, berdasarkan pendapat yang dikemukakan oleh Cooper dan Fraser (2009), terdapat beberapa faktor yang mempengaruhi kejadian pre-eklamsi yaitu keadaan sosial yang buruk, usia dan paritas ibu, riwayat gangguan hipertensi dalam keluarga, riwayat hipertensi terdahulu, dan adanya gangguan medis lainnya (penyakit ginjal, diabetes melitus, dan gangguan tromboembolisme).

Pre-eklamsia kemungkinan juga dapat disebabkan oleh faktor lain yang lebih dominan dari karakteristik, namun insiden ini sangat dipengaruhi oleh paritas yang berkaitan dengan ras dan etnis, sedangkan faktor resiko lain yang berkaitan dengan pre-eklamsia adalah kehamilan multiple, riwayat hipertensi kronik, usia ibu lebih dari 35 tahun, dan obesitas (Cuningham, 2005).

Berdasarkan hasil penelitian yang dilakukan oleh Langelo (2011), diperoleh hasil bahwa ada hubungan antara umur ibu dengan kejadian pre-eklampsia; ada hubungan antara paritas dengan kejadian pre-eklampsia, ada hubungan pemeriksaan kehamilan (ANC) dengan kejadian pre-eklampsia, dan ada hubungan antara riwayat hipertensi dengan kejadian pre-eklampsia.

Hasil penelitian yang dilakukan oleh Asitah (2009), diperoleh hasil bahwa angka kejadian pre-eklamsia pada kehamilan menurut umur ditemukan pada kelompok umur 20-35 tahun sebanyak 73\%, pre-eklamsia ditemukan pada paritas primipara sebanyak $82 \%$, pre-eklamsia ditemukan pada usia kehamilan trimester ke III sebanyak 94\%, dan pre-eklamsia ditemukan pada ibu hamil dengan riwayat kehamilan terdapat pada resiko tinggi sebanyak $67 \%$.

Berdasarkan study Pendahuluan di Poli Kebidanan Rumah Sakit Tingkat II Iskandar Muda Banda Aceh pada tahun 2013, dari jumah kehamilan sebanyak 3.787 kehamilan, dijumpai sebanyak 44 orang $(1,16 \%)$ ibu hamil mengalami hipertensi, sebanyak 106 orang $(2,79 \%)$ ibu hamil mengalami pre-eklamsia berat dan 2 orang $(0,05 \%)$ ibu hamil mengalami eklamsi. Sedangkan periode pada tahun 2014, dari 3.188 orang ibu hamil yang datang berkunjung ke Poli Kebidanan Rumah Sakit Tingkat II Kesdam, sebanyak 49 orang mengalami hipertensi $(1,53 \%)$, sebanyak 126 orang $(3,95 \%)$ mengalami preeklamsia berat dan sebanyak 4 orang $(0,15 \%)$ mengalami eklamsi. Menunjukkan bahwa angka kejadian pre-eklamsia di Rumah Sakit Tingkat II Kesdam meningkat setiap tahunnya.

\section{Tujuan Penelitian}

Untuk mengetahui hubungan umur, paritas dan riwayat hipertensi dengan pre-eklamsia pada ibu hamil di
Poli Kebidanan Rumah Sakit Tingkat II Iskandar Muda Banda Aceh Tahun 2014.

\section{METODE}

Jenis penelitian ini bersifat analitik dengan pendekatan cross sectional, yang dilakukan sejak bulan Januari sampai dengan Juli 2015 di Poli Kebidanan Rumah Sakit Tingkat II Iskandar Muda Banda Aceh. Populasi dalam penelitian ini adalah seluruh ibu hamil yang datang berkunjung ke Poli Kebidanan Rumah Sakit Tingkat II Iskandar Muda Banda Aceh, periode Januari sampai dengan Desember 2014, berjumlah 3.188 orang. Teknik pengambilan sampel dalam penelitian ini menggunakan random sampling.Besarnya sampel dalam penelitian ini dihitung menggunakan rumus Slovin sebagai berikut:

$$
\begin{aligned}
& n=\frac{N}{1+N\left(d^{2}\right)} \\
& n=\frac{3188}{1+3188\left(0,1^{2}\right)} \\
& n=\frac{3188}{1+3188(0,01)} \\
& n=\frac{3188}{1+31,88} \\
& n=\frac{3188}{32,88} \\
& n=96,95 \\
& \mathrm{n}=97 \text { orang }
\end{aligned}
$$

Keterangan :

$\mathrm{N}$ : Besar populasi

$\mathrm{n}$ : Besar sampel

d : Tingkat kepercayaan (ketepatan yang diinginkan) sebesar $90 \%$

Data yang digunakan dalam penelitian ini adalah data sekunder, yang diperoleh dari buku register atau rekam medik di Poli Kebidanan Rumah Sakit Tingkat II Iskandar Muda Banda Aceh, pada periode Januari sampai dengan Desember 2014.

Analisa data pada penelitian ini dilakukan analisa statistik dengan uji Chi-square. Dengan batas kemaknaan $(\alpha=0,05)$ atau Convident Internal $(\mathrm{CI}=95 \%)$.

\section{HASIL}

Kejadian Pre-eklamsia

Tabel 4.1 Distribusi Frekuensi Kejadian Pre-Eklamsia Pada Ibu Hamil di Poli Kebidanan Rumah Sakit Tingkat II Iskandar Muda Banda AcehTahun 2014

\begin{tabular}{clcc}
\hline No & Kejadian pre-eklamsia & Frekuensi & $\%$ \\
\hline 1 & Ya & 60 & 61,9 \\
2 & Tidak & 37 & 38,1 \\
\hline & Jumlah & 97 & 100 \\
\hline
\end{tabular}


Berdasarkan Tabel 4.1 menunjukkan bahwa dari 97 responden, sebagian besar responden mengalami preeklamsia sebanyak $61,9 \%$

Umur

Tabel 4.2 Distribusi Frekuensi Umur Ibu Hamil yang MengalamiPre-eklamsidi Poli Kebidanan Rumah Sakit Tingkat II Iskandar Muda Banda Aceh Tahun 2014

\begin{tabular}{clcc}
\hline No & \multicolumn{1}{c}{ Umur } & Frekuensi & $\%$ \\
\hline 1 & Berisiko & 34 & 35,1 \\
2 & Tidak berisiko & 63 & 64,9 \\
\hline & Jumlah & 97 & 100 \\
\hline
\end{tabular}

Berdasarkan Tabel 4.2 menunjukkan bahwa dari 97 responden, sebagian besar umur responden berada pada kategori tidak berisiko sebanyak 64,9\%.

\section{Paritas}

Tabel 4.3 Distribusi Frekuensi ParitasIbu Hamil yang Mengalami Pre-eklamsi di Poli Kebidanan Rumah Sakit Tingkat II Iskandar Muda Banda Aceh Tahun 2014

\begin{tabular}{clcc}
\hline No & \multicolumn{1}{c}{ Paritas } & Frekuensi & $\%$ \\
\hline 1 & Berisiko & 55 & 56,7 \\
2 & Tidak berisiko & 42 & 43,3 \\
\hline & Jumlah & 97 & 100 \\
\hline
\end{tabular}

Berdasarkan Tabel 4.3 menunjukkan bahwa dari 97 responden, sebagian besar paritas responden berada pada kategori berisiko sebanyak $56,7 \%$

Riwayat hipertensi

Tabel 4.4 Distribusi Frekuensi Riwayat Hipertensi Ibu Hamil yang Mengalami Pre-eklamsi di Poli Kebidanan Rumah Sakit Tingkat II Iskandar Muda Banda AcehTahun 2014

\begin{tabular}{clcc}
\hline No & Riwayat Hipertensi & Frekuensi & $\%$ \\
\hline 1 & Ada & 46 & 47,4 \\
2 & Tidak ada & 51 & 52,6 \\
\hline & Jumlah & 97 & 100 \\
\hline
\end{tabular}

Berdasarkan Tabel 4.4 menunjukkan bahwa responden yang memiliki riwayat hipertensi dan tidak memiliki riwayat hanya ada sedikit perbedaan, yang tidak memiliki riwayat hanya $52,6 \%$.

Hubungan umur ibu hamil dengan kejadian pre-eklamsi

Tabel 4.5 Hubungan Umur Ibu Hamil Dengan Kejadian Pre-eklamsi di Poli Kebidanan RumahSakit Tingkat IIIskandar Muda Banda Aceh Tahun 2014

\begin{tabular}{lllccccccc}
\hline & & \multicolumn{3}{c}{ Kejadian Pre-eklamsia } & Total & \multirow{2}{*}{$\begin{array}{c}\text { - } \\
\text { No }\end{array}$} & Umur & \multicolumn{3}{c}{ Ya } & \multicolumn{3}{c}{ Tidak } & & & Value & CI \\
\cline { 3 - 7 } & & $\mathrm{f}$ & $\%$ & $\mathrm{f}$ & $\%$ & $\mathrm{f}$ & $\%$ & & \\
\hline 1 & Berisiko & 27 & 79,4 & 7 & 20,6 & 34 & 100 & 0,017 & 0,05 \\
2 & $\begin{array}{l}\text { Tidak } \\
\text { berisiko }\end{array}$ & 33 & 52,4 & 30 & 47,6 & 63 & 100 & & \\
\hline
\end{tabular}

Berdasarkan Tabel 4.5 diperoleh hasil bahwa responden yang memiliki umur pada kategori berisiko lebih banyak mengalami pre-eklamsi yaitu79,4\%, dibandingkan responden yang memiliki umur pada kategori tidak berisiko dan mengalami kejadian preeklamsi hanya 52,4\%. Setelah dilakukan uji statistik dengan menggunakan Chi-Square dengan tingkat kepercayaan 95\%, diperoleh nilai $p=0,017 \quad(p<0,05)$, menunjukkan bahwa ada hubungan umur dengan preeklamsia pada ibu hamil di Poli Kebidanan Rumah Sakit Tingkat II Iskandar Muda Banda Aceh.

Hubungan paritas ibu hamil dengan kejadian pre-eklamsi

Tabel 4.6 Hubungan Paritas Ibu Hamil Dengan Kejadian Pre-eklamsi di Poli KebidananRumah Sakit Tingkat II Iskandar Muda Banda AcehTahun 2014

\begin{tabular}{|c|c|c|c|c|c|c|c|c|c|}
\hline \multirow{3}{*}{ No } & \multirow{3}{*}{ Paritas } & \multicolumn{4}{|c|}{ Kejadian Pre-eklamsia } & \multirow{2}{*}{\multicolumn{2}{|c|}{ Total }} & \multirow{3}{*}{$\begin{array}{c}p- \\
\text { Value }\end{array}$} & \multirow{3}{*}{$\begin{array}{c}95 \% \\
\text { CI }\end{array}$} \\
\hline & & \multicolumn{2}{|c|}{ Ya } & \multicolumn{2}{|c|}{ Tidak } & & & & \\
\hline & & $\mathrm{f}$ & $\%$ & $\mathrm{f}$ & $\%$ & $\mathrm{f}$ & $\%$ & & \\
\hline 1 & Berisiko & 40 & 72,7 & 15 & 27,3 & 55 & 100 & 0,021 & 0,05 \\
\hline 2 & $\begin{array}{l}\text { Tidak } \\
\text { berisiko }\end{array}$ & 20 & 47,6 & 22 & 52,4 & 42 & 100 & & \\
\hline
\end{tabular}

Berdasarkan Tabel 4.6 diperoleh hasil bahwa responden yang memiliki paritas pada kategori berisiko dan mengalami pre-eklamsi $72,7 \%$. Sedangkan pada responden yang memiliki paritas pada kategori tidak berisiko dan mengalami pre-eklamsi hanya 47,6\% Setelah dilakukan uji statistik dengan menggunakan Chi-Square diperoleh nilai $p=0,021(p<0,05)$, menunjukkan bahwa ada hubungan paritas dengan pre-eklamsia pada ibu hamil di Poli Kebidanan Rumah Sakit Tingkat II Iskandar Muda Banda Aceh.

Tabel 4.7 Hubungan Paritas Ibu Hamil Dengan Kejadian Pre-eklamsi di Poli Kebidanan Rumah Sakit Tingkat II Iskandar Muda Banda AcehTahun 2014

\begin{tabular}{|c|c|c|c|c|c|c|c|c|c|}
\hline \multirow{3}{*}{ No } & \multirow{3}{*}{$\begin{array}{l}\text { Riwayat } \\
\text { Hipertensi }\end{array}$} & \multicolumn{4}{|c|}{$\begin{array}{c}\text { Kejadian Pre- } \\
\text { eklamsia }\end{array}$} & \multirow{2}{*}{\multicolumn{2}{|c|}{ Total }} & \multirow[t]{3}{*}{$\begin{array}{c}p- \\
\text { Value }\end{array}$} & \multirow[t]{3}{*}{$\begin{array}{c}95 \% \\
\text { CI }\end{array}$} \\
\hline & & \multicolumn{2}{|c|}{$\mathrm{Ya}$} & \multicolumn{2}{|c|}{ Tidak } & & & & \\
\hline & & $\mathrm{f}$ & $\%$ & $\mathrm{f}$ & $\%$ & $\mathrm{f}$ & $\%$ & & \\
\hline 1 & Ada & 34 & 73,9 & 12 & 26,1 & 46 & 100 & 0,035 & 0,05 \\
\hline 2 & Tidak ada & 26 & 51 & 25 & 49 & 51 & 100 & & \\
\hline
\end{tabular}

Berdasarkan Tabel 4.7 diperoleh hasil bahwa responden yang memiliki riwayat hipertensi dan mengalami pre-eklamsi sebanyak 73,9\% dibandingkan dengan yang tidak mengalami pre-eklamsi hanya $26,1 \%$. Responden yang tidak ada riwayat hipertensi dan mengalami pre-eklamsi $51 \%$ sedangkan yang tidak mengalami pre-eklamsi $49 \%$. Setelah dilakukan uji statistik dengan menggunakan Chi-Square diperoleh nilai $p=0,035$ $(p<0,05)$, menunjukkan bahwa ada hubungan riwayat hipertensi dengan pre-eklamsia pada ibu hamil di Poli Kebidanan Rumah Sakit Tingkat II Iskandar Muda Banda Aceh. 


\section{PEMBAHASAN}

1. Hubungan umur dengan kejadian pre-eklamsia pada ibu hamil

Hasil penelitian ini sejalan dengan penelitian yang pernah dilakukan oleh Rejeki (2010), bahwa secara statistik ada hubungan yang signifikan umur dengan pre-eklamsi

Sesuai dengan teori yang dikemukakan oleh Achsin dan Ngatimin (2008) juga mengemukakan bahwa wanita yang belum berusia 20 tahun atau berusia diatas 35 tahun saat kehamilan pertama kemungkinan akan munculnya eklamsia (keracunan kehamilan). Salah satu penyakit yang tercatat sebagai penyebab kematian maternal. Ibu yang berusia tua dapat berisiko lebih besar untuk mengalami komplikasi kehamilan, disebabkan karena kelainan kromosom yang lebih tinggi terutama sindrom down. Wanita yang berusia 35 tahun cendrung untuk mempunyai masalah kronis seperti tekanan darah tinggi yang dapat mempengaruhi kehamilan dibandingkan dengan wanita yang lebih muda.

Teori ini juga didukung oleh Solihah (2008) juga mengemukakan semua ibu hamil bisa terkena pre-eklamsia. Namun yang lebih berisiko adalah ibu hamil untuk pertama kali, ibu dengan kehamilan kembar, penderita diabetes, memiliki hipertensi sebelum hamil, punya masaah ginjal dan ada riwayat pre-eklamsia dalam keluarga atau pernah menderita pre-eklamsia pada kehamilan sebelumnya, atau kehamilan pertama dibawah usia 20 tahun atau di atas 35 tahun.

2. Hubungan paritas dengan kejadian pre-eklamsia pada ibu hamil

Hasil penelitian ini sejalan dengan penelitian yang pernah dilakukan oleh Utami (2007), bahwa ibu yang memiliki paritas yang beresiko memiliki 3,3 kali untuk mengalami pre-eklamsi

Faktor paritas memiliki pengaruh terhadap persalinan dikarenakan Ibu hamil memiliki risiko lebih tinggi untuk mengalami gangguan selama masa kehamilannya terlebih pada ibu yang pertama kali mengalami masa kehamilan (Langelo, 2011).

Teori ini juga didukung oleh teori yang dikemukakan oleh Achsin dan Ngatimin (2008) juga mengemukakan bahwa wanita yang belum berusia 20 tahun atau berusia diatas 35 tahun saat kehamilan pertama kemungkinan akan munculnya eklamsia (keracunan hamil). Salah satu penyakit yang tercatat sebagai penyebab kematian maternal. Ibu yang berusia tua dapat berisiko lebih besar untuk mengalami komplikasi kehamilan, disebabkan karena kelainan kromosom yang lebih tinggi terutama sindrom down. Wanita yang berusia 35 tahun cendrung untuk mempunyai masalah kronis seperti tekanan darah tinggi yang dapat mempengaruhi kehamilan dibandingkan dengan wanita yang lebih muda.
3. Hubungan riwayat hipertensi dengan kejadian preeklamsia pada ibu hamil

Hasil penelitian ini sejalan dengan penelitian yang pernah dilakukan oleh Utami (2007), bahwa ibu yang mempunyai riwayat hipertensi memiliki peluang 7 kali untuk mengalami pre-eklamsi

Sesuai dengan teori yang dikemukakan oleh Rukiyah dan Yulianti (2011) mengemukakan faktor resiko yang dapat meningkatkan terjadinya preeklamsia adalah riwayat tekanan darah tinggi sebelum kehamilan, riwayat mengalami preeklamsia sebelumnya, riwayat pre-eklamsia pada ibu atau saudara perempuan.

Teori ini juga didukung oleh teori yang dikemukakan oleh Cuningham (2005) mengemukakan ibu hamil dengan riwayat hipretensi sebelumnya terjadi apabila ibu mengalami hipertensi kronik sebelum kehamilan. Hipretensi kronik adalah terdapat hipertensi persisten, tekanan darah lebih dari 140/90 mmHg sebelum kehamilan, atau sebelum 20 minggu. Wanita dengan penyakit vaskuler kronik, yang pertama kali diperiksa pada usia kehamilan 20 minggu, sering kali memperlihatkan tekanan darah yang normal. Namun selama trimester ketiga tekanan darah dapat kembali ke tingkat hipertensif semua, sehingga timbul masalah diagnostik dalam menentukan hipertensi yang bersifat kronik atau dipicu oleh kehamilan. Hipertensi kronik ini menyebabkan hipertrofi ventrikel dan dekompensatia kordis, cedera serebrovaskuler atau kerusakan intrinsik ginjal, yang berisiko menimbukan pre-eklamsia, yang mungkin jumpai hampir 25\% diantara para wanita ini. Pada sebagian wanita, hipertensi kronik yang sudah ada sebelumnya akan semakin memperburuk setelah usia gestasi 24 minggu Apabila disertai oleh proteinuria, akan muncul lebih dini daripada preeklamsia murni serta cenderung cukup parah dan disertai dengan hambatan pertumbuhan janin

\section{KESIMPULAN}

Ada hubungan umur, paritas dan riwayat hipertensi dengan pre-eklamsia pada ibu hamil di Poli Kebidanan Rumah Sakit Tingkat II Iskandar Muda Banda Aceh

\section{DAFTAR PUSTAKA}

Ambarwati dan Rismintari, 2009. Asuhan Kebidanan (Nifas). Jakarta : Mitra Cedikia.

Amelda, 2009. Pre-eklamsi. http://etc.ugm.com (dikutip tanggal 23 Januari 2015).

Asitah, N, 2009. Gambarankasus preeklamsiapadaibuhamil di RumahSakit Dr.Pirngadi.MedanJurnalPenelitianUniversitas Sumatera Utara.

Achsin, A \& Ngatimin, R, 2008. Untukmu ibu tercinta, Cetakan ke 1, Jakarta Timur: Prenada media. 
Betty, 2012. Hubungan Karakteristik Ibu Dengan Kejadian Pre-Eklamsia Di Rsui Yakssi Sragen. Karya Tulis Ilmiah. Akademi Kebidanan Estu Utomo Boyolali.

Cooper dan Fraser, 2009. Myles Buku Ajar Bidan. Jakarta : EGC.

Cunningham, 2005. Obstetri Williams Edisi 21. Jakarta : EGC

Depkes RI, 2010. Pedoman Pemantauan Wilayah Setempat Kesehatan Ibu dan Anak (PWS-KIA), Jakarta : Departemen Kesehatan Kesehatan Republik Indonesia.

Dinas Kesehatan Provinsi Aceh, 2013. Profil Kesehatan Provinsi Aceh. Banda Aceh.

Langelo, 2011. Faktor Risiko Kejadian Preeklampsia di RSKD Ibu Dan Anak Siti Fatimah Makassar tahun 2011-2012. Makassar : Fakultas Kesehatan Masyarakat. Universitas Hasanuddin

Prawirohadjo, 2007. Ilmu Kebidanan. Jakarta : Yayasan Bina Pustaka Sarwono Prawirohadjo.

Rahajuningsih, D, 2005. Disfungsi Endotel pada preeklamsia, journal Makara, Kesehatan, Vol. 9, No.2,
Desember 2005: 63-69 (dikutip tanggal 23 Januari 2015

Rejeki, 2010. Perilaku Patuh Perawatan Ibu Primigravida Dengankejadian Preeklamsi Berat Eklamsia di RSUD Soewondo Kendal. http://jurnal.unimus.ac.id (dikutip tanggal 23 Januari 2015).

Rukiyah dan Yulianti, 2011. Asuhan Kebidanan IV (Patologi Kebidanan). Jakarta : Trans Info Media.

Rumah Sakit Tingkat II Kesdam, (2015). Register Rekam Medik Ruang Bersalin. Banda Aceh.

Solihah, L, 2008. Panduan Lengkap Hamil sehat, cetakan ke $x$. Jogjakarta : Tiga Serangkai.

Utami, 2007. Faktor-Faktor Risiko Preeklampsia Pada Kehamilan (Studi di RSUP Dr. Soeradji Tirtonegoro Klaten). http://srirezkiamelia.com/(dikutip tanggal 23 Januari 2015). 